\title{
News loopholing: Telegram news as portable alternative media
}

\author{
Ahmed Al-Rawi ${ }^{1}$ (D) \\ Received: 7 May 2021 / Accepted: 10 December 2021 / Published online: 29 December 2021 \\ (c) The Author(s), under exclusive licence to Springer Nature Singapore Pte Ltd. 2021
}

\begin{abstract}
This paper deals with foreign state-run media outlets that disseminate Persian language news targeted to the Iranian public. More specifically, it focuses on the mobile news app Telegram by undertaking a content analysis of a sample of the top 400 most viewed stories across four channels, i.e., BBC Persian, Voice of America's Persian language service VOA Farsi, Radio Farda, and Iran International television channel. It also offers a topic modelling of all news stories posted. Results show that most of the news coverage centered on politics, particularly with an emphasis on internal Iranian issues, while a few other channels repeatedly urged their followers to submit not only their email addresses and other private information, but also photographs and/or videos of anti-government protests. Conceptually, I consider these channels as portable alternative media, as opposed to state-run news media, since the Iranian public seeks them out as sources of political information that assist them in better understanding world news and, most importantly, news about their own country. The Telegram instant messaging app is related to the meso dimension of alternative media, meaning that it is characterized by the unique production and dissemination means it utilizes. This paper concludes by highlighting the implications of foreign state-run news outlets using news loopholing to disseminate information, while simultaneously collecting private information about their users and/or potentially risking their safety.
\end{abstract}

Keywords Telegram $\cdot$ Middle East $\cdot$ Alternative media $\cdot$ Mobile apps $\cdot$ Politics $\cdot$ Iran

Ahmed Al-Rawi

aalrawi@sfu.ca

https://www.sfu.ca/communication/team/faculty/ahmed-alrawi.html

1 School of Communication, Simon Fraser University, Room \# K8645, 8888 University Dr., Burnaby, BC V5A 1S6, Canada 


\section{Introduction}

This paper empirically examines how the Telegram instant messaging app is used by foreign state-run media outlets to disseminate Persian language news to the Iranian public. Using a mixed method, the study attempts to understand the kind of news topics that these Telegram channels mostly cover, and it examines the audiences' engagement with news stories.

This paper offers two unique contributions. First, the study expands on the theoretical concept of alternative media by focusing on its meso dimension, i.e., distribution and production, which is facilitated by the introduction of new communication technologies, such as news apps. Due to online filtering imposed by Iranian authorities, the public in Iran cannot access news websites, such as BBC Persian or Iran International television channel, as well as several others, unless they use Virtual Personal Networks (VPNs). As a result, many news outlets, including the ones examined here, attempt to find news loopholes which allow them to reach their targeted audiences. In this respect, I expand on the theory of alternative journalism by introducing the concept of "news loopholing" as a means to create alternative public spheres.

Second, the data set examined here has not been explored before in political communication and news research, because it is difficult to obtain large raw data from mobile apps [7]. Thus, this case study is unique as it deals with foreign-run state media outlets targeting the population of another country. Before discussing our theoretical framework, it is important to provide some background information on the use of Telegram in Iran and the four outlets examined in this study.

It is clear that the news organizations such as BBC Persian, VOA Farsi, Radio Farda, and Iran International face a major dilemma. On the one hand, they need to report breaking and exclusive news not covered by Iranian mainstream media because of censorship, i.e., stories focused on Evin Prison, thus functioning as alternative media. Because they are not allowed to operate freely in the country, these channels are also increasingly reliant on citizen journalists, their own Telegram followers, and other volunteers to report news. From a moral obligation standpoint, news organizations have an ethical responsibility to minimize any possible harm towards their sources and audiences [53]. However, these channels do not seem keen on safeguarding their users. Instead, and with little consideration for their safety and security, they repeatedly encourage their users to take photos and videos of anti-government protests and then post them publicly. In situation, where there is some level of democratic governance, these acts might sound reasonable even when coming from foreign news agencies, but as mentioned above, Iran is an authoritarian state well-known for its persecution of journalists and activists. In fact, in 2020 Reporters without Borders ranked Iran number 173 of 180 countries in its world press freedom index [55]. Iranian authorities have arbitrarily arrested tens of local and foreign journalists and academics, often falsely accusing them of espionage. In some cases, journalists are arrested for merely posting news on Telegram and other social media outlets or for being interviewed on BBC Persian [21, 22, 70]. There are also several reports of Iranian 
activists being detained after which their oppositional Telegram channels were taken away by Iran's Revolutionary Guards to silence dissent [4, 47]. There is no doubt that citizen journalists greatly assist news organizations in their reporting of events, particularly in conflict zones and times of crises [42, 73]; however, the unique case study examined here clearly demonstrates that measures must be taken to ensure the safety of news audiences.

Another significant issue is users' privacy, as these news organizations often ask their Telegram followers to download VPNs and provide their names, email addresses, and other private information. It is not clear whether the information collected can be leaked and/or hacked by the Iranian regime, which is well-known for actively gathering intelligence on the opposition and political activists [17, 74]. It is also not clear how the information collected by the VPN companies and these news organizations is used. For example, the US State Department encourages Iranians to interact on its Telegram channel @USAdarFarsi and routinely collects information about users which is later shared with the US intelligence community [11]. This issue undoubtedly requires further scholarly and policy consideration.

The paper is structured as follows. First, I highlighted above my contributions to the literature, and then I offered an overview of Telegram use in Iran. In the following section, I offer a theoretical discussion on alternative journalism by introducing the concept of mobile apps as portable public spheres. Following the method section, I provide the results and a detailed discussion, while the conclusion focuses on the implications of the study. The paper concludes with a discussion of the problematic practices these news outlets routinely engage in, i.e., encouraging Iranians to take videos or photos of anti-government protests, even though they are fully aware of the security risks involved when undertaking citizen journalism in a repressive state, such as Iran, which routinely detains, intimidates, and harasses journalists.

\section{Mobile apps as portable alternative news media}

Previous research on alternative journalism has focused on alternative news media as distinct from mainstream news media [10]. As Jon Bekken mentions, the concept of alternative media is very fluid as it encompasses a variety of aspects, such as the "range of voices presented, the privileging of marginalized and excluded news sources over traditional elites, a conscious identification with the audience being served, and a conception of journalism that promotes social action" [16, p. 1]. However, as will be explained below, I argue that the channels examined here need to be considered alternative media outlets not because of their content, audience outreach, editorial stance, format, or nature of funding, but rather solely because of their unique process of news dissemination. That is, their news practices are meant to create alternative public spheres, wherein various audiences can articulate the concerns and issues of importance to them, which are often ignored by mainstream media [56] in Iran. In other words, they are alternative media outlets for the Iranian public. The public sphere is manifested in easily accessible platforms for deliberations, discussions, and debates which could be possible with the affordances of online venues, such as mobile apps [7, 75]. Telegram, for example, allows users to reply to 
news and make comments. Whether they find a venue to exist and thrive online or offline, such alternative public spheres are crucial for enhancing democratic practices, state accountability, and transparency [23, 41].

Broadly speaking, alternative journalism is defined as media "that reject and/ or challenge the conventions and structures of mainstream commercial or statefunded media.... [and] in which groups and individuals on the margins of mainstream culture and media can form communities of interest within which they can communicate and debate issues of mutual interest" [29]. Chris Atton's definition of alternative journalism aligns with the above description as there is an emphasis on radical media "with overt advocacy and oppositional practices [that]... emphasize first person, eyewitness accounts by participants..." [9, p. 267]. Atton's general typology of alternative media highlights two main forms: (1) products which include content, form, adaptions or innovations, and (2) processes that encompass distributive use, transformed social relations, and communication processes [8, $\mathrm{p}$. 27]. I argue that BBC Persian, VOA Farsi, Radio Farda, and Iran International are alternative, because they fall within the process element of distributive use, which refers to "alternative sites for distribution" such as employing "clandestine/invisible networks" [8, p. 27]. Atton borrows his conceptualization of clandestine alternative sites of distribution from John Downing's study on radical media, which are meant to cross-frontiers and combat hegemonic media [25, p. 83]. More recently, Holt, Figenschou, and Frischlich argue that alternative media outlets can be divided into three levels: (1) micro (content), (2) meso (distribution/production), and (3) macro (media system). Of greatest relevance to the current study is the meso level, as it specifically deals with the distribution process [32, p. 864]. In this respect, Tenenboim and Kligler-Vilenchik introduced the concept of meso news-space which is defined as an "online space, occurring between the private and public realms, where participants are involved in news-related processes" [68, p. 577]. The activities on this meso space are dependent on the platform, topic of discussion, participants, and participation guidelines [68]. Indeed, the discussion of the meso-space is relevant to this study which focuses on Telegram as a news platform and how audiences engage with news.

But the rhetorical question remains: Can we consider BBC Persian, VOA Farsi, Radio Farda, and Iran International as radical outlets aiming to spread democracy in Iran? All of these channels claim that their main goal is to enhance democracy. While such claims are not entirely inaccurate, it is crucial to examine the geostrategic and political contexts, as well as the broad mandates, of these channels. First, the United States, United Kingdom, and Saudi Arabia do not enjoy friendly relationships with Iran. In fact, some scholars [2, 59, 64] believe that the US, and to a certain extent Saudi Arabia, desire a regime change. Second, as part of larger mainstream media outlets, foreign-run media channels are mandated as public diplomacy tools that serve their respective countries' geo-political interests in the region via the dissemination of news. This means that they have huge funding that dwarfs that of radical and/or alternative news outlets [38, 48, 60]. In fact, scholars often regard state-run media, including those broadcasting in foreign languages, as propaganda channels predominantly because of their overt way of branding their countries $[19,43,62,72,81]$. In the context of this study, the latter 
notion refers to white propaganda, indicating the dissemination of factual news [34]. In other words, these channels have self-serving purposes which are not entirely related to the ideal goals of progressive radical media, such as enhancing the democratic process. Here, Downing makes a distinction between democratic radical media and repressive media, the demarcation line between the two being that the latter "maims the public's ability to develop its powers... Neither critical reflection nor any genuine increase in personal or collective freedom are on the radar screen of such media" [25, p. 89]. Interestingly, one of the examples of repressive radical media that Downing provides is the anti-Shah media that was used to support Khomeini's Islamic Revolution (p. 88). Such media is regarded as radically repressive, because the political change that occurred in Iran after 1979 limited peoples' freedom and democratic participation [27]. Alternatively, radical news outlets are supposed to be grassroot initiatives whose purpose is to enrich the democratic process, assist social movements, and enhance the public sphere.

Thus, I argue that BBC Persian, VOA Farsi, Radio Farda, and Iran International are neither repressive radical media nor democratic media. Rather, and as argued above, these channels can be understood as alternative media due to the medium and innovative method by which they reach the Iranian public whose access to information is curtailed by the repressive measures implemented by the Iranian regime. I call this approach news loopholing given that these channels found a gap or loophole in the large firewall created and maintained by the repressive Iranian regime, thus providing previously censored information to people yearning for alternative news. Because these channels want to create alternative public spheres to what the mainstream Iranian media offers, they are considered alternative media outlets due to their unique way of disseminating news that bypasses Iranian censors. This loopholing practice is enabled by new technologies, since encrypted mobile apps such as Telegram offer a customized and instantaneous venue for mass news dissemination [76, 77]. Ultimately, these channels serve as portable alternative media outlets that help produce and sustain portable public spheres whenever and wherever their users engage with them. As Khodabakhshi rightly observes, the news dissemination strategy followed by BBC Persian is a "social circumvention strategy" rather than a social media or news dissemination technique (as cited in Lichterman [40]) as these outlets bypass government censors when using mobile apps. Though the medium is different, this news loopholing approach was also used by Reporters Without Borders when they re-published the writings of Saudi dissident journalist Jamal Khashoggi in Minecraft, an online game not blocked in Saudi Arabia [26]. In brief, BBC Persian, VOA Farsi, Radio Farda, and Iran International employ a radical alternative method for disseminating news to the Iranian public; however, they are neither radically repressive nor progressive.

Telegram use in Iran There is no doubt that Iran practices repressive measures to curtail freedom of speech via networked authoritarianism practices [3, 49] - a tactic often used by other non-democratic countries, such as China, Azerbaijan, and Russia. In a networked authoritarian state, there are "no guarantee of individual rights and freedoms. People go to jail when the powers-that-be decide they are too much of a threat-and there's nothing anybody can do about it. Truly competitive, free and 
fair elections do not happen. The courts and the legal system are tools of the ruling party" (MacKinnon [44], p. 4).

Interestingly, since 2013 most of Telegram's worldwide visits have come from Iran. With 25 million active users in 2016 [35], the number of Iranian users jumped to 40 million in 2018 [45] and more than 50 million users by the end of the same year Kermani [12, 36] stated that in June 2017, 69.9\% of Telegram's visitors were Iranians. These numbers undoubtedly highlight the vital role the messaging app plays in mass communication inside Iran. Indeed, Telegram has played a significant communication role in news diffusion for Iranians despite being officially blocked by the Iranian government [3, 65].

Regarding usage purposes, a 2017 survey found that $70 \%$ of Iranians use Telegram for messaging peers and $18 \%$ use it for entertainment purposes, with half of those surveyed saying they trusted and, therefore, favoured news coming from Telegram versus traditional state-run Iranian media [67]. Moreover, in 2017 Telegram had more than 380,000 Persian channels with over two million posts published daily [36, p. 4]. More importantly, Marchant et al. [45] emphasize that much more research needs to be conducted to "effectively map the structure and dynamics of Persian-language Telegram, and additional tools are required to adapt to the specific challenges of Telegram's ... networks, a hybrid between a traditional social media platform and a conventional messaging app" [45, p. 38]. Hence, the research presented in this study fills a major gap in literature on the empirical study of mobile news.

\section{Foreign-state run Telegram news channels in Persian}

The four channels investigated in this study are BBC Persian, Voice of America's (VOA) Persian language service, Radio Farda, and Iran International television channel. First, BBC Persian was initially established as a radio channel in December 1940 to serve the British government's interests in the region [63]. The Persian branch follows the BBC's agenda which aims to engage with foreign audiences by offering them ways to contribute and share their opinions [15, p. ii]. Since BBC Persian's website is blocked in Iran, the channel emerged on the mobile app Viber, which was popular in Iran but soon got blocked as well. In 2015, BBC Persian was launched on Telegram as a breaking news platform posting an average of 20 news stories a day [40]. The Iranian regime thinks that BBC Persian's news focus, tone, and language of BBC Persian's coverage portrays it negatively [11, 13, 14]. This is one of the reasons that Iranian authorities continuously threaten, intimidate, and harass BBC Persian journalists [31, 69]. As of early January 2020, the Telegram channel of BBC Persian had the highest number of followers and views (Table 1) in relation to all other channels disseminating news content on this mobile app [66].

Second, Voice of America's (VOA) Persian language radio service, or VOA Farsi, was launched by the United States government to broadcast news in Persian language to the Middle East following the Second World War [33, p. 137]. Although the radio service started as part of VOA's West and South Asia Division, it became a unit of the Persian News Network in July 2007 (PNN) [33, p. 138]. Together with 
Table 1 Frequency of news stories and views along the four channels

\begin{tabular}{llccccc}
\hline No & Channels & No. of stories & Views & Followers & Photos & Videos \\
\hline 1 & BBC Persia & 54,349 & $156,169,921$ & $1,100,000$ & 10,500 & 10,600 \\
2 & VOA Farsi & 77,481 & $10,516,710$ & 155,000 & 22,000 & 12,500 \\
3 & Radio Farda & 42,186 & $12,627,000$ & 142,000 & 16,300 & 3180 \\
4 & Iran International & 41,220 & $11,286,220$ & 184,000 & 12,300 & 13,800 \\
& Total & 215,236 & $190,599,851$ & $1,581,000$ & 61,100 & 40,080 \\
\hline
\end{tabular}

Figures on the number of followers, photos, and videos were collected on January 11, 2020

Radio Farda, the international broadcaster is currently under the leadership of Radio Free Europe/Radio Liberty 'RFE/RL' [18].

Third, Radio Farda was created in December 2002 with offices in Prague and Washington. The focus of Radio Farda's coverage has revolved mostly around "Iranian and Western pop music" (Izadi, p. 140), a strategy that exposed the radio to conservative criticism. Similar to BBC Persian, the Iranian regime blocks Radio Farda's website and even jams its radio transmissions [50].

Finally, Iran International television channel offers a unique case as its potential funders are not fully disclosed, even though numerous reports link it to Saudi Arabia [54]. The channel began broadcasting on the day of the Iranian presidential elections in May 2017 [57], stating that it is a privately owned UK organization [1] belonging to London-based private limited company called Volant Media UK and operated by DMA Media [71]. However, evidence given by Jamal Khashoggi suggests that the channel is funded by the Saudi government, one of Iran's opponents [24, 30]. Similar to the other channels currently under investigation, the Iranian regime imposed what they called "judicial and legal restrictions" against the staff of Iran International because of the tone of its coverage regarding anti-government protests [54].

To study mobile news and understand the unique case study examined here, this paper attempts to answer the following research questions:

RQ1: What are the news topics that Telegram audiences most engage with as alternative news sources?

RQ2: As these four Telegram news channels offer alternative public spheres, what are news topics they mostly focus on in their coverage?

\section{Method}

I collected a total of 215,236 $\square$ Telegram news stories from October 2, 2015 to January 18, 2020 from 4CAT [51]. These news stories represent all those available and posted by BBC Persian, VOA Farsi, Radio Farda, and Iran International on Telegram, since the app's launch until the data collection process started (Fig. 1). There were some major events that occurred during this period such as the start of the Iran nuclear talks with Western powers and their subsequent hurdles, the international economic sanctions on Iran, the 2017 mass protests, and the January 2020 killing of General Qasem Soleimani. 


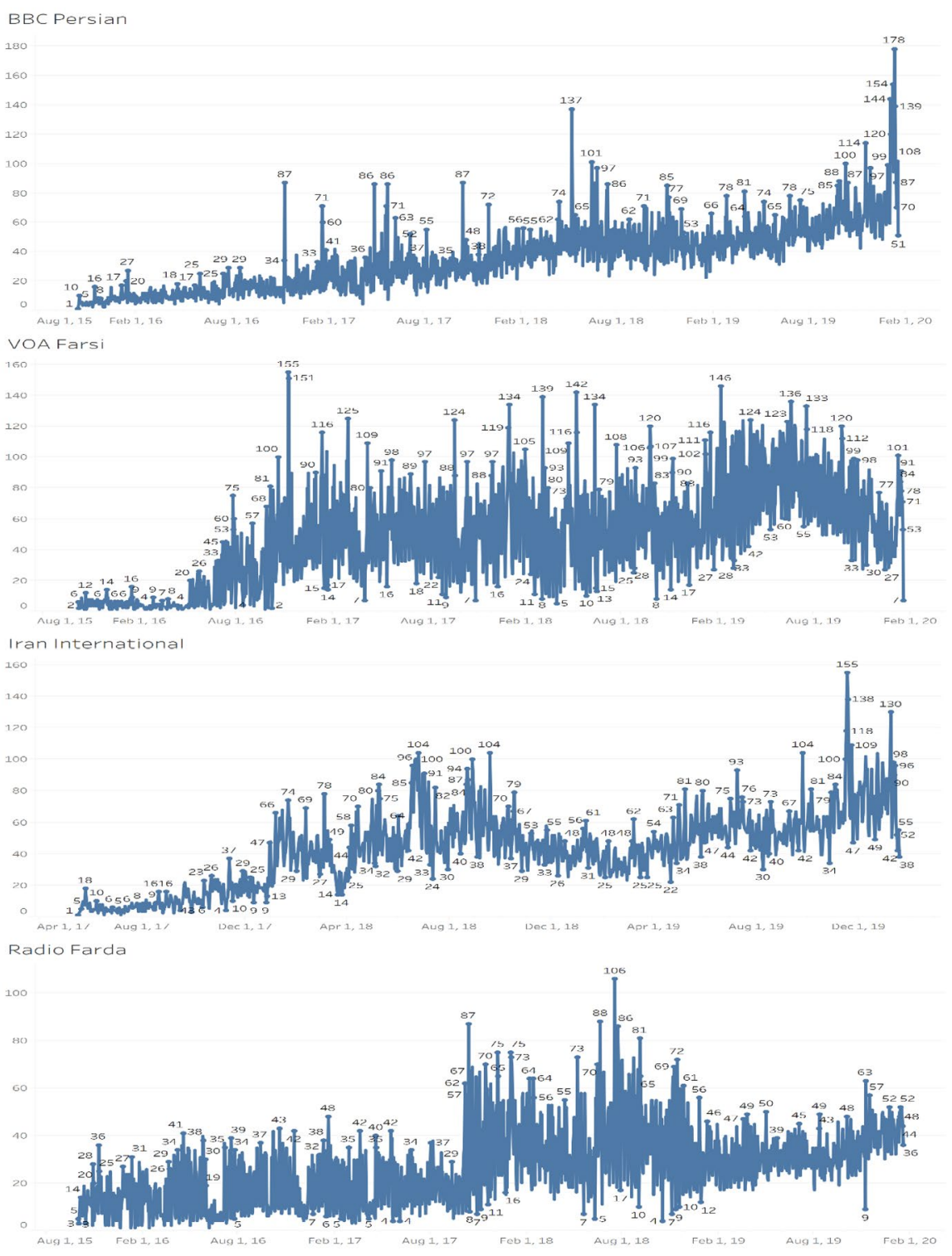

Fig. 1 Frequency of Telegram news stories along all the four news channels

In total, these news stories received 190,599,851 mobile views (Table 1). In this respect, the number of views is the only available metric I found that indicates audience engagement with Telegram news. To analyze this content, I used a mixed method. First, and because of the large data set collected, I selected the top 100 most viewed news stories from each channel ( $n=400$ in total). This method has been used by other studies analyzing large data sets from social media and 
news, where the top 50 or 100 trending or top items based on the number of retweets, likes, or shares was often selected [78, 82].

Second, using the news values method, we conducted a qualitative analysis to categorize the 400 top news stories based on their topics. This approach has been used in numerous other news content studies to understand the salience of topics $[28,61]$. Next, two coders examined a sample of the content to determine which topics to include. Ultimately, the codebook contained 7 different mutually exclusive categories: (1) politics, (2) sports, (3) entertainment, (4) anniversary/commemoration, (5) human interest, (6) general news, and (7) others. For each news topic, the coders assigned the scope as either internal, i.e.) deals with internal Iranian affairs, or international, i.e.) also includes the regional dimension (Table 2). However, not all news stories, especially those related to general news items, had a clear scope. To ensure that our codebook was valid, two coders manually examined $10 \%$ of the sample $(n=40)$ and the intercoder reliability for nominal data [37] was acceptable using Krippendorff's Alpha for all topics $\alpha \geq 0.77$ and stories with scope $\alpha \geq 0.88$. The detailed breakup of the intercoder reliability tests are: (A) Topics: (1) politics $\alpha \geq 0.80$; (2) sports $\alpha \geq 0.65$; (3) entertainment $\alpha \geq 1.00$; (4) anniversary/commemoration $\alpha \geq 0.65$; (5) human interest $\alpha \geq 0.69$; (6) general news $\alpha \geq 0.69$; and (7) others $\alpha \geq 0.87$ (B) Scope: (1) no clear scope $\alpha \geq 0.94$; (2) national scope $\alpha \geq 0.852$; and (3) international scope $\alpha \geq 0.75$. The remaining data set was then manually coded by a coder fluent in both Farsi and English.

To complement the first phase of this research, I also used a digital method examining all the news stories $(n=215,236 \square)$ to understand the similarities and differences between audiences' most viewed news stories and the overall prominence of news topics in each channel. In this regard, I used topic modelling, a machine learning method that provides an automated analysis of unstructured data. Using QDA Miner 5-Word Stat 8 software, this research employs Factor Analysis (FA) in topic modeling to identify the latent semantic concept. Here FA indicates "factor loading," which refers to "the strength of the relationship of each word to each topic," while the data "dimensionality reduction in FA is based on the idea that each word is the representation of a linear combination of underlying hidden variables (i.e., topics)" [52]. For this current study, I used the mathematical linear system of the Eigenvalue to rank the topics with $>1$ value rule following Kaiser's criteria [46, p. 145]. The higher the Eigenvalue, the more prominent the topic is in the text corpus $[5,6]$. Due to the lack of space, I only focused on the top 5 topics for each of the four Telegram news channels examined in this study. In brief, the manual content analysis in the first stage of the study was used to understand audience's engagement with news topics and classify stories into topics in an attempt to answer the first research question. The second stage of the study involved using topic modelling, which is a digital method that automatedly identifies topics in an unstructured text, to investigate the news coverage as a whole and answer the second research question. These two approaches are complementary to each other, for the main topics generated from the second stage of the study were also manually classified into general types. For example, the "Football National Team" topic is considered sports, while "Donald Trump" is regarded as politics (Table 3 ). 


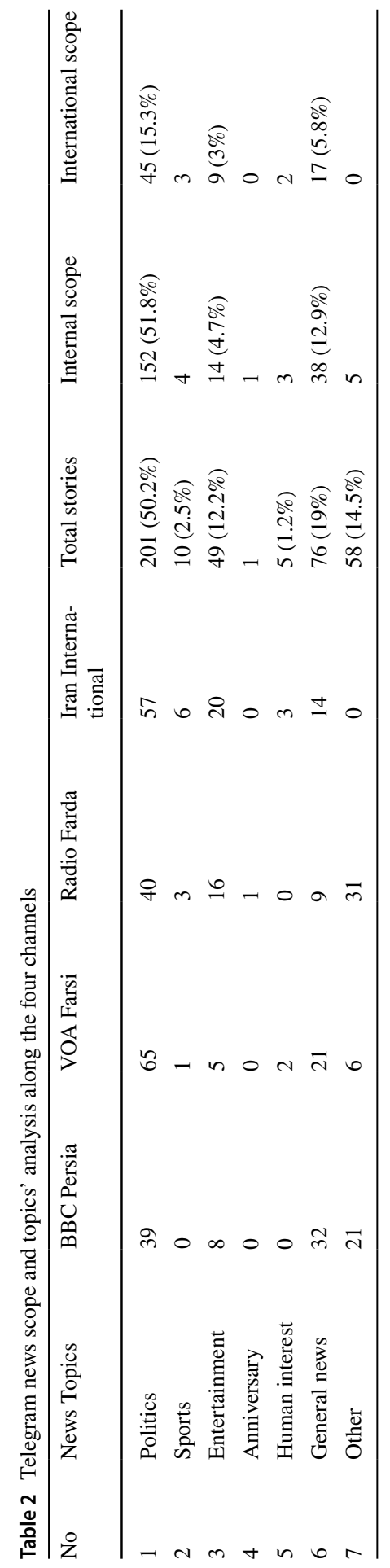




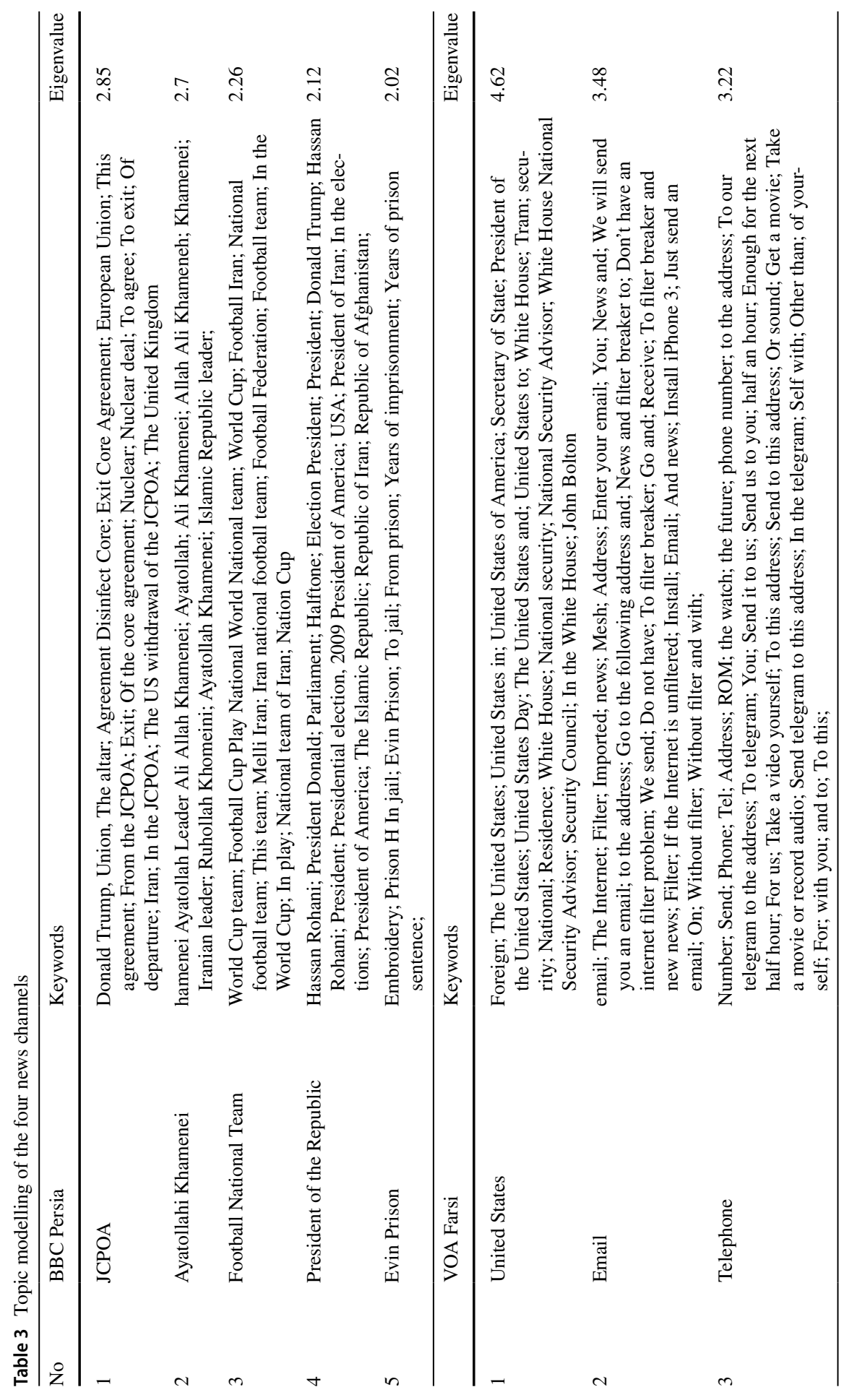




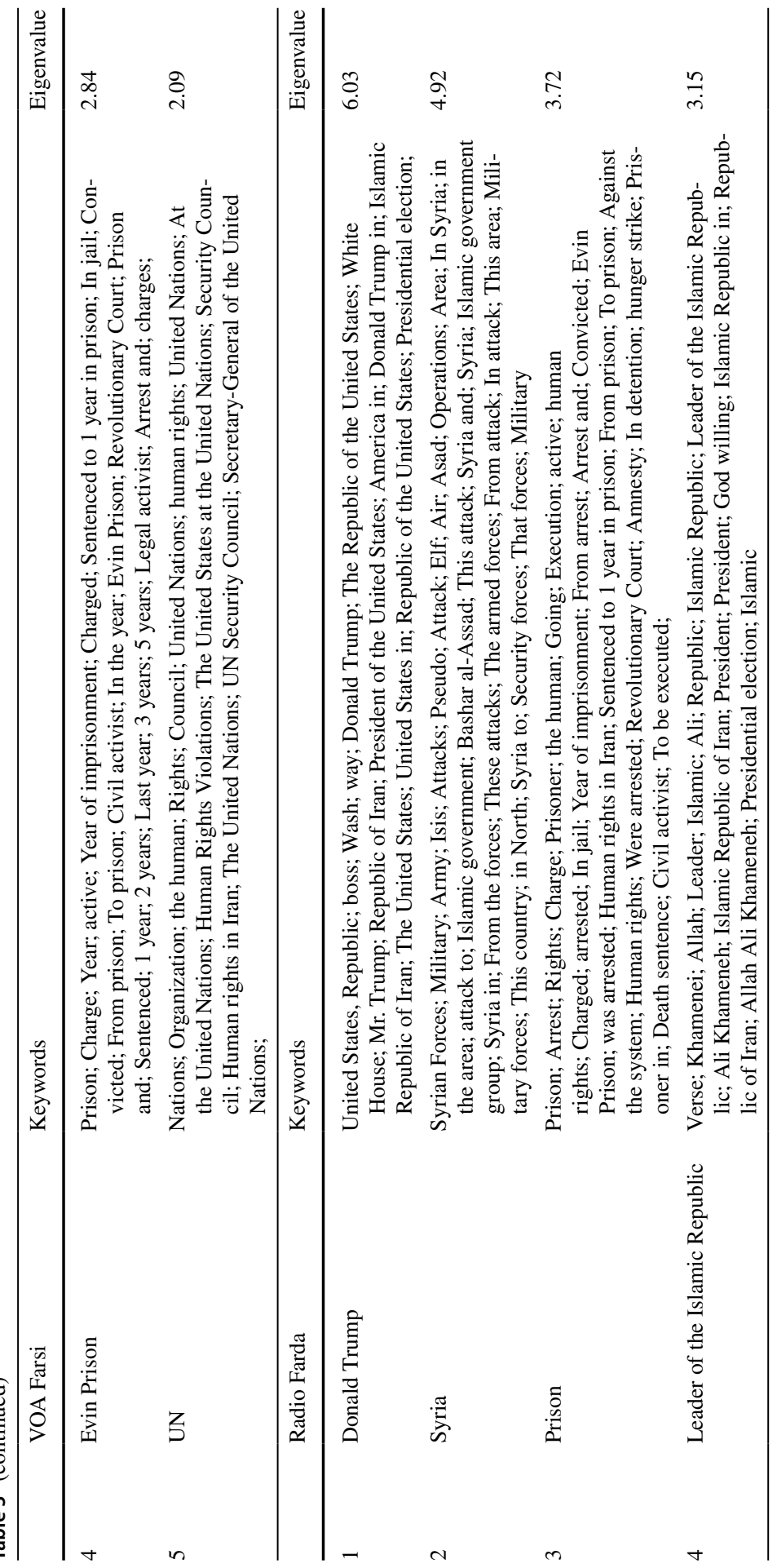




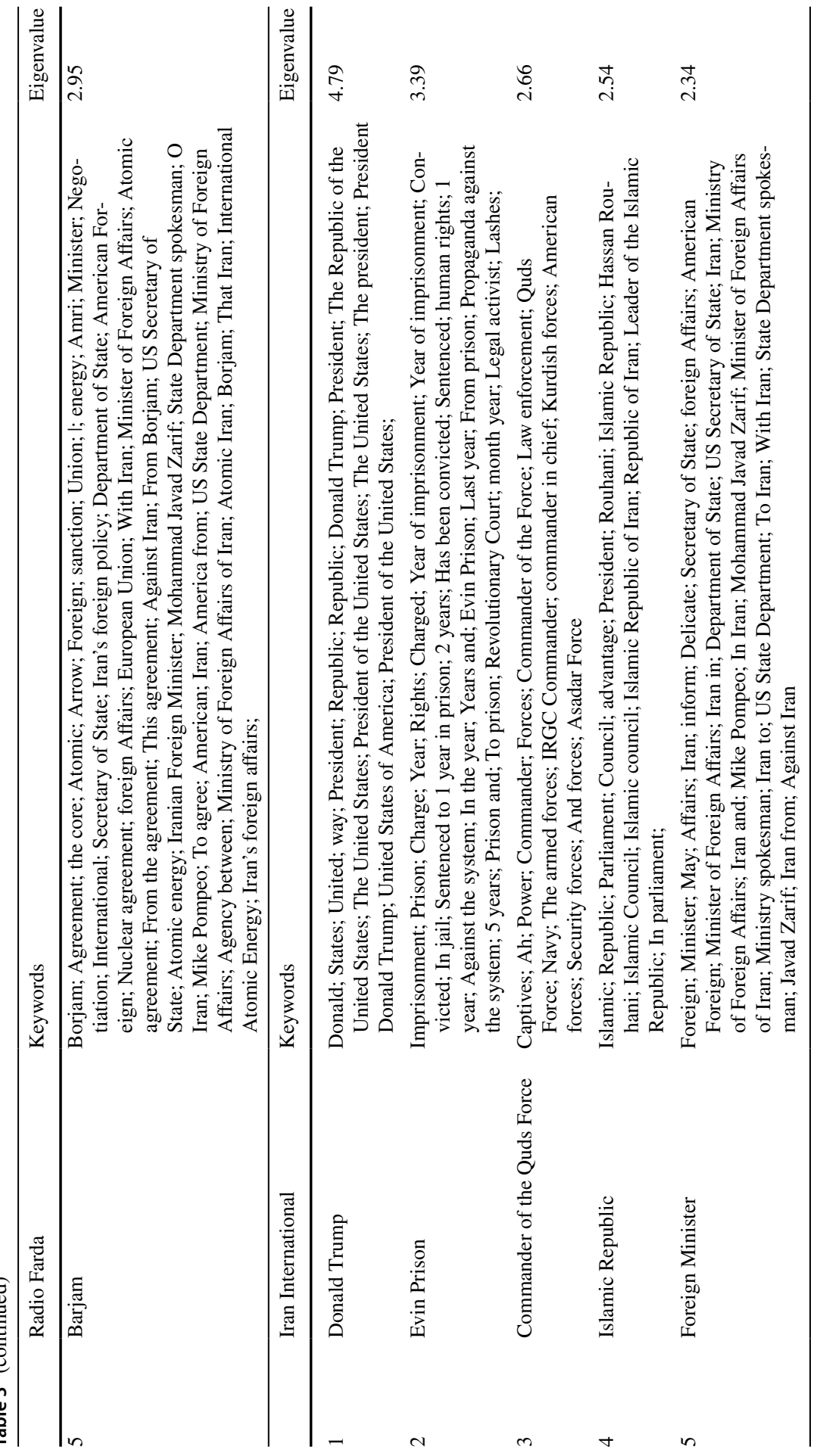




\section{Results and discussion}

This study examines BBC Persian, VOA Farsi, Radio Farda, and Iran International, four foreign state-run media outlets that disseminate Persian language news targeted to the Iranian public. With regard to the first research question concerning the news topics Telegram audiences engage with most, we found that politics is the most engaged with topic across all four channels, constituting $50.2 \%$ or over half the news coverage $(n=201)$. In terms of the scope of politics, internal political affairs garner most of the audience's attention in Iran $51.8 \%(n=152)$ versus international politics $15.3 \%(n=45)$. In fact, across all examined news topics, Iranian Telegram users were far more interested in internal news $74 \%(n=217)$ than international news $26 \%$ $(n=76)$. In addition, Fig. 1 indicates audience's interest in internal politics, for we can see clear emphasis on political news based on the most viewed news items. For instance, BBC Persian's most viewed stories were on January 11, 2020 and concerned follow-up reports on the crash of a Ukrainian International Airlines flight and Iran's missile attack on a US military base in Iraq. Iran International's most viewed stories were on November 17, 2019 and dealt with Iran's supreme leader's decision to raise gasoline prices by $50 \%$ following street protests. As for VOA Farsi, the most viewed stories are on November 8, 2016 following the announcement that Trump has been elected US president, while Radio Farda's most viewed stories were on July 18, 2018 and dealt with protests by Iranian teachers against their low salaries and reports on Iran's faltering nuclear deal with the UN. If we take into account all the news channels' news coverage, we find that two dates received the highest number of audience views. The first is May 8, 2018 when President Trump announced that the US would pull out of the Iran nuclear deal and the second is January 8, 2020 when Iran announced Operation Martyr Soleimani, Iran's Islamic Revolutionary Guard Corps (IRGC) missile attack on a US airbase in western Iraq. To sum up, the audiences' most viewed stories shed important light on their interest in hard news primarily focused on internal Iranian politics.

I believe that the impetus for the audiences' interest in internal politics is threefold. First, and based on the results of three audience surveys, Iranians, especially youth, are highly interested in political news [58, p. 63]. Second, because Iranians want to be informed and updated on their own country's political rapid developments, they seek out news from these alternative media channels, which complement information disseminated by official Iranian news sources. There is no doubt that breaking news stories are urgently needed by and directly relevant to ordinary Iranians whose lives are affected by sanctions and ongoing political tensions. Third, Iranians' interest in politics is driven by the high level of censorship in their country, where democratic discussion of government accountability and transparency is not allowed [3, 49, 80]. This surely affects the level of trust Iranians have in official news sources. According to a Gallup survey, many Iranians do not find official sources to be trustworthy [39]. This lack of trust is a result of several years of cover-ups and propaganda dissemination, including the number of casualties reported in Iran's military interventions in the region, COVID19 deaths, the 2020 downing of a Ukrainian airplane [20, 79]. 
The second most engaging topic was general news about various minor issues such as the repeated calls for using VPNs and/or accessing them via emails $19 \%$ $(n=76)$. BBC Persian is one of the most active channels disseminating such news, which also includes health advice such as " necessary recommendations before the earthquake @ Bbcpersian" (3 times, 8,164,947 total views) or "See if honey and lemon juice really prevent coughing? Which syrup should be used for what type of cough? Watch this video \# 37 and send it to your friends @ BBCPersian" $(2,515,695$ views). Once again, general news on internal Iranian issues was twice as engaging $12.9 \%(n=38)$ than international general news $5.8 \%(n=17)$. Other prominent news topics included entertainment $12.2 \%(n=49)$, especially in relation to Iran's music and film industry, and human-interest stories $1.2 \%(n=5)$ (See Table 2).

Regarding the second research question, which was concerned with the major topics covered by all four news organizations, I found that 17 out of 20 topics dealt with politics. Given its coverage of Iran's national football team, BBC Persian is the only channel that had sports as one of the top five topics (Table 3). Similar to the topics preferred by Telegram users, there is a clear emphasis on hard news and an obvious focus on political elites, such as the US President, Iran's Foreign Minister and President, and Qassim Soleimani, the former Commander of the Quds Force. The only common topic across all four channels was Evin Prison in Tehran, which was mentioned 755 times. The prison houses most of Iran's political prisoners, including foreign academics and journalists. Many of these news stories referred to the death of Sina Ghanbari, a political activist, who died in the notorious prison in January 2018 allegedly due to torture. Furthermore, Iran International referenced the term "political activist" 348 times in different contexts, indicating an emphasis on covering protests and human rights abuses.

In terms of recurrent topics, and based on the strength of their Eigenvalues, I found that the US State Department's Radio Farda highlights "Donald Trump" much more than any other topic across all the four channels $(\lambda \geq 6.03)$. Except for BBC Persian, the topic of "Donald Trump" was also prominent across the other media channels given the US President's fierce engagement with Iran from the beginning of his presidency, i.e., imposing more economic sanctions, terminating the nuclear talks, limiting Iran's political influence in the Middle East, and the military confrontation in Iraq which killed General Qassim Soleimani. Another common topic was Iran's nuclear deal or the Joint Comprehensive Plan of Action (JCPOA), also known as Barjam, which was referenced 646 times on BBC Persian alone. This topic is indirectly referenced via mentions of the UN by VOA Farsi and the prevalence of references to President Donald Trump.

Also of note was VOA Farsi's active strategy of urging audiences to use their phones to take and then email videos of protests and political unrest. For example, the Telegram channel often mentions the following: "Do you have any information about the location and status of a friend or family member in custody? What is the duty of a citizen to maintain the rights of detainees? Take a movie from yourself or record a sound and send it to this address in telegram @sendVOA." Another similar message reads: ""Death to Khamenei" and "Referendum, Referendum", This is the slogan of the people in Azadi St., Tehran. Send photos and videos to VOA's Telegram channel $€$ @ sendVOA". In terms of "Email" topic, 
it refers to the channel's recommendation to download the Psiphon VPN tool and share the "information with loved ones". The repeated message also states: "If you want wireless internet, install Siphon3. Just email: €et@Psiphon3.com." VOA Farsi is not unique here as Radio Farda once urged its users to "send your photos from today's election to info@radiofarda.com," while BBC Persian's top four most viewed posts also contain hyperlinks, thus promoting the same VPN tool to access the Telegram news channels. This general news item is repeatedly updated and received 3,805,741 views. It states the following:

Circumvention to access News.

If you're having trouble accessing BBC News sites, this page provides information about the tools available to access these sites. When using this tool, you must not risk yourself or others to be compromised or under the law. Use of this tool to receive news may be illegal based on regulations. If you use this tool, you need to follow caution. Please read the terms and conditions of use of the BBC. https://bbc.in/ 2HKs066@(Psiphon).

To download the VPN tool, BBC Persian often asks its users to use the Tor Browser of the Dark Web. If the bowser is blocked, the channel recommends sending an email to the Tor project requesting that they set it up or using other VPN apps, such as Lantern, Opera Max or Opera Mini.

To conclude, the four Telegram news channels examined here have found a news loophole by which to disseminate alternative news, thus bypassing Iran's firewall. The intention of alternative media outlets such as BBC Persian, VOA Farsi, Radio Farda, and Iran International is to create a personalized venue that can assist Iranians in navigating news about their own country and the world, while simultaneously offering them news from the perspective of these channels' sponsors. However, if these channels are keen on maintaining their credibility among Iranian audiences they must also work to protect their users' physical safety and privacy.

This study offers a new conceptualization of alternative news in relation to the concept of news loopholing and the exclusive use of the meso dimension. In this sense, mobile news apps can create alternative public spheres that are portable in nature. By enforcing news dissemination though loopholes in the Iranian statedesigned firewall, these Telegram channels attempt to attract and maintain their news audience who often seek alternative sources of news. This is an interesting case which can be found and studied in other national contexts and media outlets especially those using new emerging technologies.

Regarding the study's limitation, this paper has only focused on four foreign state-run media outlets that disseminate news in the Persian language targeted to Iranian audiences. It does not include other popular Telegram news channels targeting Iranians from Russia or Turkey. Thus, it is important to conduct cross-national comparative research on mobile news that can fill another major gap in literature, particularly as it concerns states known to practice networked authoritarianism. In addition, we conducted a content analysis in the first stage of the study of the top 100 most viewed Telegram stories, so there must have been some reduction in the data analysis. Hence, future studies could include more stories that can be manually 
analyzed. Finally, there are other mobile apps that can be included in future studies especially independent media that are run by the Iranian diaspora.

Acknowledgements I would like to thank the graduate students: Elly Habiblluah, Abdelrahman Fakida, and Nawal Motut from the School of Communication at Simon Fraser University for their kind assistance in coding, copy editing, and/or writing parts of the literature review.

\section{References}

1. Iran International. (2020). About Iran International. Retrieved from https://iranintl.com/en/aboutiranintl. Accessed 28 Dec 2021.

2. Ahmadian, H. (2018). Iran and Saudi Arabia in the age of Trump. Survival, 60(2), 133-150.

3. Akbari, A., \& Gabdulhakov, R. (2019). Platform surveillance and resistance in Iran and Russia: The case of Telegram. Surveillance \&amp; Society, 17(1/2), 223-231.

4. Al-Monitor. (2019). Arrest of Telegram channel operator surprises Iranians. Retrieved from https:// www.al-monitor.com/pulse/originals/2019/10/arrest-telegram-operator-iran-iraq.html. Accessed 28 Dec 2021

5. Al-Rawi, A. (2019). Gatekeeping fake news discourses on mainstream media versus social media. Social Science Computer Review, 37(6), 687-704.

6. Al-Rawi, A. (2019). Viral news on social media. Digital journalism, 7(1), 63-79.

7. Al-Rawi, A. (2020). Mobile news apps as sites of transnational ethnic mediascapes. The Journal of International Communication, 26(1), 73-91.

8. Atton, C. (2002). Alternative media. Sage.

9. Atton, C. (2003). What is alternative journalism? Journalism, 4(3), 267-272.

10. Atton, C., \& Hamilton, J. F. (2008). Alternative journalism. Sage.

11. Atwood, (2020). US uses encrypted app to connect with Iranians as coronavirus sweeps their country. CNN. https://www.cnn.com/2020/03/18/politics/state-department-coronavirus-iran-outreach/ index.html. Accessed 28 Dec 2021

12. BBC. (2018). Iran restricts Telegram messaging app. Retrieved from https://www.bbc.com/news/ technology-43907246. Accessed 28 Dec 2021.

13. BBC Persian. (2009). اه نناسر هاكن زا عس ىب عب عسراف نوىزىولت. Retrieved from http://www. bbc.co.uk/persian/world/2009/01/090109_ka_mgh_ptv_other_media.shtml. Accessed 28 Dec 2021.

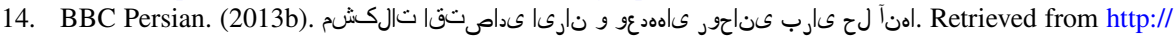
www.bbc.co.uk/persian/iran/2013/08/130804_142_vid_ir_eco.shtml. Accessed 28 Dec 2021.

15. BBC Strategy Review. (2010). Retrieved from http://www.bbc.co.uk/bbctrust/assets/files/pdf/ review_report_research/strategic_review/strategy_review.pdf. Accessed 28 Dec 2021.

16. Bekken, J. (2015). Alternative journalism. In W. Donsbach (Ed.), The International encyclopedia of communication. Wiley.

17. Berman, I. (2020). The Fight for Iran: Opposition Politics, Protest, and the Struggle for the Soul of a Nation. Rowman \& Littlefield Publishers.

18. Biener, H. (2003). The arrival of radio Farda: International broadcasting to Iran at a crossroads. Middle East, 7(1), 13.

19. Boyd, D. A. (2003). Sharq Al-Adna/The Voice of Britain: The UK's 'Secret' Arabic Radio Station and Suez War Propaganda Disaster. International Communication Gazette, 65(6), 443-455.

20. Bozorgmehr, N. (2020) Lies over downing of aircraft shake Iran's trust in its rulers. The Financial Times. Retrieved from https://www.ft.com/content/86df67f6-3524-11ea-a6d3-9a26f8c3cba4. Accessed 28 Dec 2021.

21. Committee to Protect Journalists. (2020a). Iranian journalist Hassan Fathi begins 1.5 year jail term over BBC interview. Retrieved from https://cpj.org/2020/05/iranian-journalist-hassan-fathi-begins15-year-jai/. Accessed 28 Dec 2021.

22. Committee to Protect Journalists. (2020b) Iranian authorities detain journalist Mohammad Mosaed again for social media posts Retrieved from https://cpj.org/2020/02/iranian-authorities-detain-journ alist-mohammad-mos/. Accessed 28 Dec 2021. 
23. Dahlberg, L. (2007). The Internet, deliberative democracy, and power: Radicalizing the public sphere. International Journal of Media \&amp; Cultural Politics, 3(1), 47-64.

24. Dehghan, S. (2018). Concern over UK-based Iranian TV channel's links to Saudi Arabia. Retrieved from https://www.theguardian.com/world/2018/oct/31/concern-over-uk-based-iranian-tv-channelslinks-to-saudi-arabia. Accessed 28 Dec 2021.

25. Downing, J. D. (2001). Radical media: Rebellious communication and social movements. Sage.

26. Gerken, T. (2020). Minecraft 'loophole' library of banned journalism. BBC News. Retrieved from https://www.bbc.com/news/world-us-canada-51883247. Accessed 28 Dec 2021.

27. Gheissari, A. (2009). Democracy in Iran: History and the quest for liberty. Oxford University Press.

28. Harcup, T., \& O'neill, D. (2001). What is news? Galtung and Ruge revisited. Journalism studies, 2(2), 261-280.

29. Harcup, T. (2014). Alternative media. In: T. Harcup (Ed.). A dictionary of journalism. Oxford University Press.

30. Homaeefar, M. (2020). Guardian reporter speaks out on Neda Agha-Soltan, Jamal Khashoggi, Iran International TV, Masih Alinejad. Tehran Times. Retrieved from https://www.tehrantimes.com/ news/445759/Guardian-reporter-speaks-out-on-Neda-Agha-Soltan-Jamal-Khashoggi. Accessed 28 Dec 2021.

31. Human Rights Watch. (2018). Iran: Activists' families facing harassment. Retrieved from https:// www.hrw.org/news/2018/08/09/iran-activists-families-facing-harassment. Accessed 28 Dec 2021.

32. Holt, K., Figenschou, T., \& Frischlich, L. (2019). Key dimensions of alternative news media. Digital Journalism, 7(7), 860-869.

33. Izadi, F. (2009). US International Broadcasting: The Case of Iran. The Journal of Arts Management, Law, and Society, 39(2), 132-148.

34. Jowett, G. S., \& O’Donnell, V. (2018). Propaganda \&amp; persuasion. Sage Publications.

35. Kermani, H. (2016). Participant observation in telegram groups: Roadmap and a case study. Journal of Culture-Communication Studies, 17(35), 53-79.

36. Kermani, H. (2020). Decoding telegram: Iranian users and 'Produsaging' discourses in Iran's 2017 Presidential Election. Asiascape: Digital Asia. https://doi.org/10.1163/22142312-12340119

37. Krippendorff, K. (2004). Content analysis: An introduction to its methodology. SAGE.

38. Kruckeberg, D., \& Vujnovic, M. (2005). Public relations, not propaganda, for US public diplomacy in a post-9/11 world: Challenges and opportunities. Journal of Communication Management, 9(4), 296-304.

39. Kucera, J. (2012). Iranians Might Watch State-Run Media, but They Don't Trust It. The Atlantic. Retrieved from https://www.theatlantic.com/international/archive/2012/06/iranians-might-watchstate-run-media-but-they-dont-trust-it/258800/. Accessed 28 Dec 2021.

40. Lichterman, J. (2017). How BBC Persian is using Instagram and Telegram to get around Iranian censorship. Neiman Lab. Retrieved from https://www.niemanlab.org/2017/02/how-bbc-persian-isusing-instagram-and-telegram-to-get-around-iranian-censorship/. Accessed 28 Dec 2021.

41. Loader, B., \& Mercea, D. (2011). Networking democracy? Social media innovations and participatory politics. Information, Communication \&amp; Society, 14(6), 757-769.

42. Loke, J., \& Grimm, J. (2017). Cast Aside: Journalists' perceptions of citizen journalists' content during the Boston marathon bombings. Journalism Practice, 11(1), 101-114.

43. Ma, V. (2016). Propaganda and censorship: Adapting to the modern age. Harvard International Review, 37(2), 46.

44. MacKinnon, R. (2010). Networked authoritarianism in China and beyond: Implications for global internet freedom. Liberation Technology in Authoritarian Regimes. Hoover Institution \& the Center on Democracy, Development and the Rule of Law (CDDRL), Stanford University, Berlin, pp. 1-31.

45. Marchant, J., Ormson, T., Honari, A., \& Sabeti, A. (2018). \#iranvotes2017: Analysing the 2017 Iranian Presidential Elections through Telegram, Twitter and Instagram. Small Media.

46. Marcus, M., \& Minc, H. (1988). Introduction to Linear Algebra. Dover.

47. Martin, A. (2019). Iranian dissident arrested and Telegram channel seized by revolutionary guard. SkyNews. Retrieved from https://news.sky.com/story/iranian-dissident-arrested-and-telegram-chann el-seized-by-revolutionary-guard-11836314. Accessed 28 Dec 2021.

48. Melissen, J. (2005). The new public diplomacy. Palgrave Macmillan.

49. Michaelsen, M. (2018). Authoritarian practices in the digital agel transforming threats to power: The International Politics of Authoritarian Internet Control in Iran. International Journal of Communication, 12, 21.

50. O'Rourke, P. J. (2010). Facts meet freedom: on the air in Afghanistan. World Affairs, 173(4), 7-20. 
51. Peeters, S., \& Hagen, S. (in press). The 4CAT capture and analysis toolkit: A modular tool for transparent and traceable social media research. Computational Communication Research. https://doi. org/10.2139/ssrn.3914892. https://ssrn.com/abstract=3914892.

52. Péladeau, N., \& Davoodi, E. (2018). Comparison of latent Dirichlet modeling and factor analysis for topic extraction: A lesson of history. In Proceedings of the 51st Hawaii International Conference on System Sciences. (pp. 615-623).

53. Plaisance, P. L. (2013). Media ethics: Key principles for responsible practice. Sage Publications.

54. Radio Free Europe. (2019). Iran takes measures against staff Of U.K.-Based TV Channel. Retrieved from https://www.rferl.org/a/iran-takes-measures-against-staff-of-u-k--based-tv-channel/30293506. html. Accessed 28 Dec 2021.

55. Reporters without Borders. (2020). World Press Freedom Index. Retrieved from https://rsf.org/en/ ranking. Accessed 28 Dec 2021.

56. Rodríguez, C. (2001). Fissures in the mediascape: An international study of citizens' media. Hampton.

57. Rosen, A. (2020). Iranian exiles use creativity and tech smarts to get real news past the regime's censors. Retrieved from https://www.fastcompany.com/90246678/iranian-exiles-use-creativity-andtech-smarts-to-get-real-news-past-the-regimes-censors. Accessed 28 Dec 2021.

58. Seyed-Emami, K. (2008). Youth, politics, and media habits in Iran. In M. Semati (Ed.), Media, culture, and society in Iran (pp. 57-68). Routledge.

59. Simon, S. (2018). Iran and President Trump: What Is the Endgame? Survival, 60(4), 7-20.

60. Snow, N. (2004). US public diplomacy in an age of propaganda. In B. H. Bagdikian, L. Artz, N. Badii, N. Botha, N. Chitty, D. J. Collison, G. Cowan, A. de Beer, M. E. Hashem, Z. He, \& D. Hull (Eds.), War, media, and propaganda: A global perspective (pp. 17-24). New York: Rowman \& Littlefield.

61. Shoemaker, P., \& Cohen, A. (2012). News around the world: Content, practitioners, and the public. Routledge.

62. Snow, N., \& Taylor, P. M. (2006). The revival of the propaganda state: US propaganda at home and abroad since 9/11. International Communication Gazette, 68(5-6), 389-407.

63. Sreberny, A., \& Torfeh, M. (2014). Persian service: The BBC and British interests in Iran. Bloomsbury Publishing.

64. Tajbakhsh, K. (2019). Getting Real About Iran. Foreign Affairs. March 19. Retrieved from https:// www.foreignaffairs.com/articles/iran/2019-03-19/getting-real-about-iran. Accessed 28 Dec 2021.

65. Telegram. (2021). Telegram FAQ. Retrieved from https://telegram.org/faq. Accessed 28 Dec 2021.

66. Telegram Analytics. (2020). News \& mass media. Retrieved from https://tgstat.com/news. Accessed 28 Dec 2021.

67. Telegram Messenger Maintains Status in Iran. (2017). Retrieved from https://financialtribune.com/ articles/sci-tech/68681/telegram-messenger-maintains-status-in-iran. Accessed 28 Dec 2021.

68. Tenenboim, O., \& Kligler-Vilenchik, N. (2020). The Meso news-space: Engaging with the news between the public and private domains. Digital Journalism, 8(5), 576-585.

69. UN News. (2020). Iran: BBC and other broadcast journalists harassed; families threatened - UN experts. Retrieved from https://news.un.org/en/story/2020/03/1059251. Accessed 28 Dec 2021.

70. Van Santen, R. (2020). Want to know what's really going on in Iran? A lesson for the news industry. Poynter. Retrieved from https:/www.poynter.org/business-work/2020/want-to-know-whats-reallygoing-on-in-iran-a-lesson-for-the-news-industry/. Accessed 28 Dec 2021.

71. Walker, J. (2019). News services company running Iran International TV expands into Brussels with buyout. Retrieved from https://www.pressgazette.co.uk/news-services-company-running-iraninternational-tv-expands-into-brussels-with-buyout/. Accessed 28 Dec 2021.

72. Walker, C., \& Orttung, R. W. (2014). Breaking the news: The role of state-run media. Journal of Democracy, 25(1), 71-85.

73. Wall, M., \& Zahed, S. E. (2015). Embedding content from Syrian citizen journalists: The rise of the collaborative news clip. Journalism, 16(2), 163-180.

74. Wege, C. A. (2019). Iranian Counterintelligence. International Journal of Intelligence and CounterIntelligence, 32(2), 272-294.

75. Wei, R., Huang, J., \& Zheng, P. (2018). Use of mobile social apps for public communication in China: Gratifications as antecedents of reposting articles from WeChat public accounts. Mobile Media \&amp; Communication, 6(1), 108-126.

76. Westlund, O. (2013). Mobile news: A review and model of journalism in an age of mobile media. Digital journalism, 1(1), 6-26. 
77. Westlund, O. (2015). News consumption in an age of mobile media: Patterns, people, place, and participation. Mobile Media \&amp; Communication, 3(2), 151-159.

78. Wilkinson, D., \& Thelwall, M. (2012). Trending Twitter topics in English: An international comparison. Journal of the American Society for Information Science and Technology, 63(8), 1631-1646.

79. Wintour, C. (2020). Journalists quit Iranian state broadcaster over crash cover-up. Financial Times. Retrieved from https://www.ft.com/content/86df67f6-3524-11ea-a6d3-9a26f8c3cba4. Accessed 28 Dec 2021.

80. Yalcintas, A., \& Alizadeh, N. (2020). Digital protectionism and national planning in the age of the internet: The case of Iran. Journal of Institutional Economics, 16(4), 519-536.

81. Zhang, J., \& Cameron, G. T. (2004). The structural transformation of China? s propaganda: An Ellulian perspective. Journal of Communication Management, 8(3), 307-321.

82. Zhao, J., Cao, N., Wen, Z., Song, Y., Lin, Y. R., \& Collins, C. (2014). \# FluxFlow: Visual analysis of anomalous information spreading on social media. IEEE Transactions on Visualization and Computer Graphics, 20(12), 1773-1782.

Publisher's Note Springer Nature remains neutral with regard to jurisdictional claims in published maps and institutional affiliations. 